\title{
Effect of organic manures and liquid organic manures on growth, yield and economics of aerobic rice cultivation
}

\author{
DIVYA SAHARE* AND AVINASH MAHAPATRA \\ Department of Agronomy, College of Agriculture, Indira Gandhi Krishi Vishwavidyalaya, RAIPUR (C.G.) INDIA \\ (Email : divya.sahare@gmail.com)
}

\begin{abstract}
Field experiment was conducted to know the response of organic manures on growth, yield, quality and economics of aerobic rice during Kharif 2011 at MARS, Dharwad. Results indicated that among organic treatments combined application of EC(1/3) $+\mathrm{VC}(1 / 3)+$ GLM(1/3) equivalent to RDF + FYM in combination with foliar application of jeevamrut @ 5001 ha $^{-1}$ at planting, 30 and 60 DAS + panchagavya @ 5 per cent at panicle emergence and flowering stages recorded significantly higher growth parameters with higher grain yield (3837 kg $\left.\mathrm{ha}^{-1}\right)$ and straw yield (5855 $\left.\mathrm{kg} \mathrm{ha}^{-1}\right)$ which was on par with control treatments i.e., RDF + FYM and RDF only. But the net return (Rs.36,366) was higher with combined application of $\mathrm{EC}(1 / 3)+\mathrm{VC}(1 / 3)+\mathrm{GLM}(1 / 3)$ equivalent to RDF + FYM in a combination with foliar application of jeevamrut @ $5001 \mathrm{ha}^{-1}$ at planting, 30 and $60 \mathrm{DAS}+$ cow urine @ 10 per cent at panicle emergence and flowering stages and B:C (2.49) was higher with combined application of $\mathrm{EC}(1 / 3)+\mathrm{VC}(1 / 3)+\operatorname{GLM}(1 / 3)$ equivalent to RDN + cow urine @ 10 per cent at panicle emergence and flowering stages this might be due to lower cost of cultivation with these treatments.
\end{abstract}

Key Words : Aerobic rice, Jeevamrut, Panchagavya, Grain yield, Net returns

View Point Article : Sahare, Divya and Mahapatra, Avinash (2015). Effect of organic manures and liquid organic manures on growth, yield and economics of aerobic rice cultivation. Internat. J. agric. Sci., 11 (1): 183-188.

Article History : Received : 24.11.2014; Revised : 11.12.2014; Accepted : 24.12.2014

\footnotetext{
* Author for correspondence
} 